\title{
Updates on the Treatment of Erythrodermic Psoriasis
}

\author{
Yang Lo' \\ Tsen-Fang Tsai ${ }^{2}$ \\ 'Department of Dermatology, Cathay \\ General Hospital, Taipei, Taiwan; \\ ${ }^{2}$ Department of Dermatology, National \\ Taiwan University Hospital and National \\ Taiwan University College of Medicine, \\ Taipei, Taiwan
}

\begin{abstract}
Erythrodermic psoriasis (EP) is a rare variant of psoriasis, which is potentially life threatening and often resistant to conventional therapy. Biologics have revolutionized the treatment of plaque-type psoriasis, and shown promise in EP. However, due to the lack of head-to-head studies and the rarity of EP, no high level evidence-based treatment guidelines for EP have been established, and the evidence of treatment of EP is limited to case reports or small case series. Here, we present a narrative review focusing on the up-to-date information for the treatment of EP.
\end{abstract}

Keywords: erythrodermic psoriasis, treatment

Erythrodermic psoriasis (EP), a rare variant of psoriasis vulgaris, accounts for $1-2 \%$ patients with psoriasis. ${ }^{1,2}$ A higher prevalence of EP in Asians was found in China and Taiwan study. ${ }^{3,4}$ EP is clinically defined as prominent erythema and scaling affecting at least $75-90 \%$ of the body surface area (BSA). ${ }^{1,5}$ Due to the extensive cutaneous involvement, EP patients can present with systemic symptoms, such as pruritus, fever, chills, dehydration, arthralgia, asthenia and lymphadenopathy. ${ }^{1,5}$ Several triggers for causing EP can be identified, including infection, administration of systemic corticosteroids, withdrawal of medication, severe emotional stress and preceding illness. ${ }^{2,6}$ Many biomarkers are possibly related to the pathogenesis of EP, including higher IL-4 and IL-10 levels, ${ }^{7}$ elevation of serum IgE ${ }^{8}$ increased Th2 response, ${ }^{7,9}$ and the presence of circulating adhesion molecules. ${ }^{10}$ There may be overlap between the EP and atopic dermatitis immune phenotypes. ${ }^{11}$ Recently, a study from China revealed the possible role of the cytokine tumor necrosis factor-related weak inducer of apoptosis (TWEAK) in the pathogenesis of EP and psoriasis vulgaris (PV). ${ }^{12}$ Furthermore, according to a recent study from China, a higher prevalence of thyroid dysfunction was found in EP patients. ${ }^{13}$ Several human leukocyte antigens (HLA), such as HLA-Cw6 and HLA-DR7 have been linked with psoriasis vulgaris, ${ }^{14,15}$ and the same genetic constitution was also related to guttate psoriasis. ${ }^{16}$ In Chinese patients with erythrodermic psoriasis, HLA- $\mathrm{C}^{*}$ 01:02 was reported to be the most frequent HLA-C allele (34.4\%) compared to plaque psoriasis $(21.9 \%)$ and healthy controls $(21.2 \%){ }^{6}$ Recently, one case reported mutations of the CARD14 gene with EP related to requiring higher doses of ustekinumab. ${ }^{17}$ Due to the lack of head-to-head studies and the rarity of EP, no high-level evidence-based treatment guidelines for EP have been established. ${ }^{1}$ This review article aims to provide up-to-date information for the treatment of EP (Tables 1-5).
Correspondence: Tsen-Fang Tsai

Tel +886-2-23I2-3456 \#65734

Email tftsai@yahoo.com 
Table I Studies of Conventional Oral Immunosuppressive Agents in EP Patients

\begin{tabular}{|c|c|c|c|c|c|}
\hline Treatment & Author (Year) & $\begin{array}{l}\text { Number } \\
\text { of } \\
\text { Subjects }\end{array}$ & $\begin{array}{l}\text { Study } \\
\text { Design }\end{array}$ & Results & Adverse Events \\
\hline MTX & $\begin{array}{l}\text { Collins et al } \\
199 \mid\end{array}$ & 7 & $\mathrm{R}$ & $\begin{array}{l}4(57.1 \%) \text { Patients with excellent response, } 2(28.6 \%) \text { patients } \\
\text { with good response, I patient failed. }\end{array}$ & NR \\
\hline MTX & $\begin{array}{l}\text { Kumar et } \mathrm{al}^{21} \\
(1994)\end{array}$ & 5 & $\mathrm{R}$ & $\begin{array}{l}2(40 \%) \text { Patients achieved disease-free interval for } 14 \text { weeks. } \\
\text { All patients relapse within } 14 \text { weeks. }\end{array}$ & Nausea, vomiting \\
\hline CsA & $\begin{array}{l}\text { Giannotti et } \mathrm{al}^{26} \\
(1993)\end{array}$ & 33 & $\begin{array}{l}\text { Case } \\
\text { series }\end{array}$ & $\begin{array}{l}22(67 \%) \text { Patients achieved complete remission in a median } \\
\text { time of } 2-4 \text { months after } 6 \text { months of treatment. }\end{array}$ & $\begin{array}{l}\text { Hypertension, } \\
\text { cerebrovascular } \\
\text { disorder }\end{array}$ \\
\hline CsA & $\begin{array}{l}\text { Bruzzese et } \mathrm{al}^{27} \\
(2009)\end{array}$ & I & $\begin{array}{l}\text { Case } \\
\text { report }\end{array}$ & $\begin{array}{l}\text { Under CsA } 3 \mathrm{mg} / \mathrm{kg} \text {, complete remission was seen within } 3 \\
\text { months. }\end{array}$ & NR \\
\hline $\begin{array}{l}\text { CsA }+ \\
\text { etretinate }\end{array}$ & $\begin{array}{l}\text { Kokelj et } \mathrm{al}^{33} \\
(1998)\end{array}$ & 3 & $\begin{array}{l}\text { Case } \\
\text { series }\end{array}$ & After treatment for $1 \mathrm{I}-18$ days, remission was seen. & $\begin{array}{l}\text { Xerosis, chelitis, GI } \\
\text { upset }\end{array}$ \\
\hline CsA + UVB & $\begin{array}{l}\text { Franchi et } \mathrm{al}^{35} \\
(2004)\end{array}$ & 7 & $\begin{array}{l}\text { Case } \\
\text { series }\end{array}$ & $\begin{array}{l}\text { After } 9 \text { weeks, PASI score } \\
\text { Reduction by } 57.6 \text {, compared with placebo. points }\end{array}$ & None \\
\hline $\begin{array}{l}\text { Acitretin } \\
\text { CsA }\end{array}$ & $\begin{array}{l}\text { Charbit et } \mathrm{al}^{36} \\
(2016)\end{array}$ & $\begin{array}{l}2 \\
2\end{array}$ & $\mathrm{R}$ & $\begin{array}{l}\text { After } 3 \text { months of treatment, } 2 \text { patients treated with acitretin } \\
\text { failed to achieve greater than } 50 \% \text { clearance. } \\
\text { I patient treated with CsA had "good" response (>75\%). }\end{array}$ & NR \\
\hline Etretinate & $\begin{array}{l}\text { Kim et a }{ }^{39} \\
(1991)\end{array}$ & 12 & $\begin{array}{l}\text { Case } \\
\text { series }\end{array}$ & $\begin{array}{l}\text { Averaged } 19.9 \text { days for complete disappearance of scales. } \\
\text { After 2-II months of treatment, } 10 \text { (83.3\%) patients } \\
\text { had satisfactory results. }\end{array}$ & $\begin{array}{l}\text { Cheilitis, elevated } \\
\text { lipid profiles level }\end{array}$ \\
\hline Etretinate & $\begin{array}{l}\text { Rosińska et al }{ }^{40} \\
(1988)\end{array}$ & 5 & $\begin{array}{l}\text { Case } \\
\text { series }\end{array}$ & 2 (40\%) Patients with clinical improvement. & Focal osteoporosis \\
\hline MMF & $\begin{array}{l}\text { Geilen et } \mathrm{al}^{47} \\
(1998)\end{array}$ & 2 & $\begin{array}{l}\text { Case } \\
\text { series }\end{array}$ & $\begin{array}{l}\text { After treatment for } 6 \text { weeks, both patients reported with } \\
70 \% \text { skin improvement. }\end{array}$ & None \\
\hline
\end{tabular}

Abbreviations: CsA, cyclosporine; EP, erythrodermic psoriasis; GI, gastrointestinal; MTX, methotrexate; MMF, mycophenolate mofetil; NR, not reported; PASI, Psoriasis Area and Severity Index; R, retrospective; UVB, ultraviolet B.

\section{Methods}

The electronic databases of PubMed, Embase and Google Scholar were searched for relevant studies from 1985 to March 1, 2021, using the index words, "erythrodermic psoriasis" and the co-indexing terms "treatment", "management", "biologic", " methotrexate", "cyclosporine", "acitretin", “ etanercept", "infliximab", "adalimumab", "ustekinumab", "secukinumab", "ixekizumab", "brodalumab", "guselkumab", " tildrakizumab", "risankizumab" and "apremilast".

\section{Conventional Oral Immunosuppressive}

\section{Agents}

\section{Methotrexate}

Methotrexate (MTX) is one of the most commonly used immunosuppressive drugs for EP. ${ }^{18-24}$ The treatment dosing is variable for the initial dose; the administration of 7.5 to $15 \mathrm{mg}$ per week for maintenance was reported based on previous retrospective studies. ${ }^{18-21,23}$ Dosing of 7.5 to $40 \mathrm{mg}$ weekly for the treatment of EP has been reported. ${ }^{1}$ Most of the patients in previous studies reported good response to MTX, ${ }^{18-20}$ and Haustein et al reported the treatment response to MTX was observed within 1 to 4 weeks, ${ }^{20}$ and 28 (77.8\%) patients had good outcomes. ${ }^{20}$ Inconsistent results were seen for child patients based on one retrospective study; among three child patients with EP under MTX, one patient did not achieve a disease-free status, but the others had approximately 14 weeks of disease-free interval. ${ }^{21}$ Aydin et al reported good responses for two patients treated with a combination of cyclosporine and MTX, ${ }^{22}$ and MTX was administered with $10 \mathrm{mg}$ intramuscular injection weekly and combined with cyclosporine $3.5 \mathrm{mg} / \mathrm{kg} / \mathrm{day}$ in divided doses. However, the time to 
Table 2 Studies of Tumor Necrosis Factor Antagonist in EP Patients

\begin{tabular}{|c|c|c|c|c|c|}
\hline Biologic Agent & \multicolumn{5}{|l|}{ Characteristics } \\
\hline Etanercept & \multicolumn{5}{|c|}{ Fully humanized, soluble, recombinant fusion protein } \\
\hline Infliximab & \multicolumn{5}{|c|}{ Mouse-human chimeric monoclonal antibody, $\lg G \mid$} \\
\hline Adalimumab & \multicolumn{5}{|c|}{ Fully humanized, monoclonal antibody, IgGI } \\
\hline Golimumab & \multicolumn{5}{|c|}{ Fully humanized, monoclonal antibody, $\lg G \mid \kappa$} \\
\hline Treatment & Author (Year0 & $\begin{array}{l}\text { Number } \\
\text { of } \\
\text { Subjects }\end{array}$ & $\begin{array}{l}\text { Study } \\
\text { design }\end{array}$ & Results & Adverse Events \\
\hline Infliximab + acitretin & $\begin{array}{l}\text { Takahashi et al }{ }^{43} \\
(2007)\end{array}$ & 7 & $\begin{array}{l}\text { Case } \\
\text { series }\end{array}$ & $\begin{array}{l}\text { After third infusion of infliximab, all patients } \\
\text { reported } 90 \% \text { improvement. }\end{array}$ & None \\
\hline Etanercept & $\begin{array}{l}\text { Esposito et } \mathrm{al}^{48} \\
(2006)\end{array}$ & 10 & $\begin{array}{l}\text { Case } \\
\text { series }\end{array}$ & $\begin{array}{l}\text { At week } 12,5 / 10(50 \%) \text { patients achieved } \\
\text { PASI } 75 . \\
\text { At week } 24,6 / 10(60 \%) \text { patients achieved or } \\
\text { maintained PASI } 75,2 / 10 \text { patients }(20 \%) \\
\text { maintained improvement between PASI } 50 \\
\text { and PASI } 75 .\end{array}$ & UTI pruritus \\
\hline Etanercept & $\begin{array}{l}\text { Piqué-Duran } \\
\text { et } \mathrm{al}^{49}(2007)\end{array}$ & I & $\begin{array}{l}\text { Case } \\
\text { report }\end{array}$ & Achieved PASI 100 at week 9 & NR \\
\hline Infliximab Etanercept & $\begin{array}{l}\text { Romero-Maté } \\
\text { et } \mathrm{al}^{50}(2010)\end{array}$ & I & $\begin{array}{l}\text { Case } \\
\text { report }\end{array}$ & $\begin{array}{l}\text { At week } 20 \text {, achieved PASI } 100 \text { with } \\
\text { infliximab. Maintained etanercept therapy for } \\
34 \text { months }\end{array}$ & NR \\
\hline $\begin{array}{l}\text { Infliximab }(n=24) \\
\text { Adalimumab }(n=7) \\
\text { Etanercept }(n=6) \\
\text { Ustekinumab }(n=3) \\
\text { Efalizumab }(n=2)\end{array}$ & $\begin{array}{l}\text { Viguier et } \mathrm{al}^{5 \mathrm{I}} \\
(20 \mathrm{II})\end{array}$ & 28 & $\mathrm{R}$ & $\begin{array}{l}\text { At week } 12-14,48 \% \text { achieved PASI } 75 \text { with } \\
\text { infliximab, } 50 \% \text { with adalimumab, } 40 \% \text { with } \\
\text { etanercept. }\end{array}$ & $\begin{array}{l}\text { Bacterial infection in } 7 / \\
12 \text { serious adverse } \\
\text { event. } \\
\text { Adalimumab: } \\
\text { lymphoma. } \\
\text { Ustekinumab: sudden } \\
\text { death. } \\
\text { Infliximab: } \\
\text { immunoallergic } \\
\text { reaction, suicide } \\
\text { attempt. }\end{array}$ \\
\hline Etanercept Infliximab & $\begin{array}{l}\text { Sahel et al } \\
2016\end{array}$ & 2 & $\begin{array}{l}\text { Case } \\
\text { report }\end{array}$ & $\begin{array}{l}\text { At week } 12 \text {, one case with etanercept from } \\
\text { PASI } 32.8 \text { to } 7 \text {. The other one improved to } \\
\text { PASI } 4.8 \text { with infliximab }\end{array}$ & NR \\
\hline Etanercept + MTX & $\begin{array}{l}\text { Fraga et a }{ }^{53} \\
(2011)\end{array}$ & I & $\begin{array}{l}\text { Case } \\
\text { report }\end{array}$ & $\begin{array}{l}\text { After } 3 \text { months of treatment, erythroderma } \\
\text { resolved. }\end{array}$ & None \\
\hline Infliximab & $\begin{array}{l}\text { Poulalhon et al } \\
\text { (2006) }\end{array}$ & 5 & $\begin{array}{l}\text { Case } \\
\text { series }\end{array}$ & $\begin{array}{l}\text { After I } 4 \text { weeks, } 2 \text { ( } 40 \%) \text { patients achieved } \\
\text { PASI 90, and } 3 \text { patients achieved PASI } 75 .\end{array}$ & $\begin{array}{l}\text { Arthralgia, delayed } \\
\text { infusion reaction, } \\
\text { pneumonia. }\end{array}$ \\
\hline Infliximab + MTX & $\begin{array}{l}\text { Lisby et al }{ }^{55} \\
(2004)\end{array}$ & 3 & $\begin{array}{l}\text { Case } \\
\text { series }\end{array}$ & $\begin{array}{l}\text { All patients with total clearance after first } \\
\text { dose of infliximab. }\end{array}$ & None \\
\hline Infliximab + MTX & $\begin{array}{l}\text { Heikkila et al }{ }^{56} \\
(2005)\end{array}$ & 4 & $\begin{array}{l}\text { Case } \\
\text { series }\end{array}$ & $\begin{array}{l}\text { All patients reported rapidly improvement } \\
\text { after } 2 \text { or } 3 \text { infusions of infliximab. }\end{array}$ & None \\
\hline
\end{tabular}


Table 2 (Continued).

\begin{tabular}{|c|c|c|c|c|c|}
\hline \multirow{2}{*}{$\begin{array}{l}\text { Biologic Agent } \\
\text { Infliximab }\end{array}$} & \multicolumn{5}{|c|}{ Characteristics } \\
\hline & $\begin{array}{l}\text { Torii et } \mathrm{al}^{59} \\
(201 \mathrm{I})\end{array}$ & 8 & UCT & $\begin{array}{l}\text { At week } 50,4(50 \%) \text { with reduction of }>5 \text { in } \\
\text { DLQI. }\end{array}$ & Nasopharyngitis \\
\hline Golimumab & $\begin{array}{l}\text { Lee et } \mathrm{al}^{70} \\
(2015)\end{array}$ & 1 & $\begin{array}{l}\text { Case } \\
\text { report }\end{array}$ & $\begin{array}{l}82 \% \text { Reduction in PASI score after the third } \\
\text { injection. }\end{array}$ & None \\
\hline
\end{tabular}

Abbreviations: CsA, cyclosporine; DLQI, Dermatology Life Quality Index; EP, erythrodermic psoriasis; MTX, methotrexate; NR, not reported; PASI, Psoriasis Area and Severity Index; R, retrospective; TNF, tumor necrosis factor; UCT, uncontrolled clinical trial; UTI, urinary tract infection.

Table 3 Studies of IL-12/23, IL-23 Antagonist in EP Patients

\begin{tabular}{|c|c|c|c|c|c|}
\hline $\begin{array}{l}\text { Biologic } \\
\text { Agent }\end{array}$ & Targets & \multicolumn{4}{|c|}{ Characteristics } \\
\hline Ustekinumab & $\begin{array}{l}\mathrm{p} 40 \text { Subunit of IL-12 } \\
\text { and }-23\end{array}$ & \multicolumn{4}{|c|}{ Fully humanized, monoclonal antibody, $\lg G \mid \kappa$} \\
\hline Guselkumab & p40 Subunit of IL -23 & \multicolumn{4}{|c|}{ Fully humanized, monoclonal antibody, lgGI } \\
\hline Risankizumab & p40 Subunit of IL -23 & \multicolumn{4}{|c|}{ Fully humanized, monoclonal antibody, IgGI } \\
\hline Treatment & Author (Year) & $\begin{array}{l}\text { Number } \\
\text { of } \\
\text { Subjects }\end{array}$ & $\begin{array}{l}\text { Study } \\
\text { Design }\end{array}$ & Results & $\begin{array}{l}\text { Adverse } \\
\text { Events }\end{array}$ \\
\hline Ustekinumab & Pescitelli et $\mathrm{al}^{74}(2015)$ & 22 & $\mathrm{R}$ & $\begin{array}{l}\text { At week } 16,70 \% \text { of patients achieved PASI } 75 \text {. More } \\
\text { than } 80 \% \text { at week } 28 \text {. }\end{array}$ & None \\
\hline Ustekinumab & $\begin{array}{l}\text { Santos-Juanes et } \mathrm{al}^{75} \\
(2010)\end{array}$ & 2 & Case series & $\begin{array}{l}\text { At week } 4 \text {, PASI score improvement: } 81 \% \text { and } 94 \% \text {, } \\
\text { respectively. At week I2, PASI score improvement: } 94 \% \\
\text { and } 97 \% \text {, respectively. }\end{array}$ & NR \\
\hline Ustekinumab & Wang et $\mathrm{al}^{76}(20 \mathrm{II})$ & 8 & Case series & $\begin{array}{l}\text { At week } 12 \text { and } 28,50 \% \text { of patients achieved PASI } 75 \text {. } \\
12.5 \% \text { achieved } \\
\text { PASI } 90 \text { at } 12 \text { weeks, and } 37.5 \% \text { achieved PASI } 90 \text { at } 28 \\
\text { weeks. }\end{array}$ & NR \\
\hline Ustekinumab & $\begin{array}{l}\text { Saraceno et } \mathrm{al}^{80} \\
(2013)\end{array}$ & 2 & Case series & $\begin{array}{l}\text { Both of patients achieved PASI at week } 12 \text {. } \\
\text { One case maintained PASI } 75 \text { for } 12 \text { months. } \\
\text { One case maintained PASI } 90 \text { for } 64 \text { weeks. }\end{array}$ & NR \\
\hline Guselkumab & Sano et $\mathrm{al}^{86}(2018)$ & 11 & Case series & At week $16,10(90.9 \%)$ with treatment success. & $\begin{array}{l}4(36.4 \%) \\
\text { Patients with } \\
\text { nasopharyngitis. }\end{array}$ \\
\hline Guselkumab & Megna et al ${ }^{87}(2020)$ & 1 & $\begin{array}{l}\text { Case } \\
\text { report }\end{array}$ & $\begin{array}{l}\text { After } 20 \text { weeks of treatment, patient achieved PASI } 100 \text {, } \\
\text { and maintaining to week } 48 .\end{array}$ & NR \\
\hline Guselkumab & Chiang et al ${ }^{88}(2021)$ & 13 & Case series & $\begin{array}{l}\text { PASI } 75 \text { rate: At weeks } 4,12,20 \text {, and } 28 \text { was } 15.4 \% \text {, } \\
38.5 \%, 53.9 \% \text {, and } 46.2 \% \text {. }\end{array}$ & None \\
\hline Risankizumab & Suleiman et al ${ }^{89}(2020)$ & 4 & $\begin{array}{l}\text { Phase } 3 \\
\text { open-label } \\
\text { clinical trial }\end{array}$ & At week 16, all patients achieved PASI 90. & NR \\
\hline
\end{tabular}

Abbreviations: EP, erythrodermic psoriasis; IL, interleukin; NR, not reported; PASI, Psoriasis Area and Severity Index. 
Table 4 Studies of IL-I7 Antagonist in EP Patients

\begin{tabular}{|c|c|c|c|c|c|}
\hline $\begin{array}{l}\text { Biologic } \\
\text { Agent }\end{array}$ & Targets & \multicolumn{4}{|c|}{ Characteristics } \\
\hline Secukinumab & Anti-IL-I7A & \multicolumn{4}{|c|}{ Fully humanized, monoclonal antibody, $\lg G \mid \kappa$} \\
\hline Ixekizumab & Anti-IL-I7A & \multicolumn{4}{|c|}{ Humanized, monoclonal antibody, lgG4 } \\
\hline Brodalumab & Anti-IL-I7R & \multicolumn{4}{|c|}{ Fully humanized, monoclonal antibody, lgG2 } \\
\hline Treatment & Author (Year) & $\begin{array}{l}\text { Number } \\
\text { of } \\
\text { Subjects }\end{array}$ & $\begin{array}{l}\text { Study } \\
\text { Design }\end{array}$ & Results & Adverse Events \\
\hline Secukinumab & Weng et $\mathrm{al}^{90}(2018)$ & 10 & $\begin{array}{l}\text { Case } \\
\text { series }\end{array}$ & $\begin{array}{l}\text { At week } 16,4(40 \%) \text { achieved PASI } 90,(70 \%) \text { of } \\
\text { patients achieved PASI } 75 \text {. At week } 24,30 \% \text { achieved } \\
\text { PASI } 90 \text { and } 60 \% \text { achieved PASI } 75 \text {. }\end{array}$ & None \\
\hline Secukinumab & $\begin{array}{l}\text { Mugheddu et } \mathrm{a}^{91} \\
(2017)\end{array}$ & 2 & $\begin{array}{l}\text { Case } \\
\text { series }\end{array}$ & $\begin{array}{l}2 \text { (I00\%) Patients achieved PASI } 75 \text { at week } 4 . \\
\text { Maintained efficacy were seen at } 12-24 \text { week } \\
\text { follow-up. }\end{array}$ & None \\
\hline Secukinumab & $\begin{array}{l}\text { Mateu-Puchades } \\
\text { et } \mathrm{al}^{92}(20 \mid 8)\end{array}$ & 5 & $\begin{array}{l}\text { Case } \\
\text { series }\end{array}$ & $\begin{array}{l}3(60 \%) \text { Patients achieved } \\
\text { PASI } 75 \text { at week } 4 \text {. All patients achieved PASI } 90 \text { at } \\
\text { week } 16 \text { and } 80 \% \text { had PASI } 100 \text {. }\end{array}$ & NR \\
\hline Secukinumab & Galluzzo et $\mathrm{al}^{93}$ (2018) & I & $\begin{array}{l}\text { Case } \\
\text { report }\end{array}$ & At week 12, the patients achieved PASI 75. & None \\
\hline Secukinumab & $\begin{array}{l}\text { Rongioletti et } \mathrm{al}^{94} \\
(2018)\end{array}$ & I & $\begin{array}{l}\text { Case } \\
\text { report }\end{array}$ & At week 12, the patients achieved PASI 100. & None \\
\hline Secukinumab & Pizzatti et al ${ }^{99}(2020)$ & I & $\begin{array}{l}\text { Case } \\
\text { report }\end{array}$ & $\begin{array}{l}7 \text { days after injection, PASI score improved from } \\
31.5 \text { to } 17.6 \text {. }\end{array}$ & None \\
\hline Ixekizumab & Saeki et al ${ }^{101}(2017)$ & 8 & $\begin{array}{l}\text { Case } \\
\text { series }\end{array}$ & $\begin{array}{l}\text { At week 52, } 8 \text { (100\%) patients achieved PASI75, } 6 \\
(75 \%) \text { achieved } \\
\text { PASI90, and I patient achieved PASI } 100 .\end{array}$ & $\begin{array}{l}\text { Allergic } \\
\text { reaction, infection, } \\
\text { injection site reaction, } \\
\text { hepatic disorder }\end{array}$ \\
\hline Ixekizumab & Megna et al ${ }^{103}(2019)$ & I & $\begin{array}{l}\text { Case } \\
\text { report }\end{array}$ & $\begin{array}{l}\text { After } 6 \text { weeks, patient achieved PASI } 100 \text {, and } \\
\text { maintaining to week } 24 \text {. }\end{array}$ & None \\
\hline $\begin{array}{l}\text { Ixekizumab + } \\
\text { acitretin, } \\
\text { Secukinumab }\end{array}$ & $\begin{array}{l}\text { Pangilinan et } \mathrm{al}^{105} \\
(2020)\end{array}$ & $\begin{array}{l}1 \\
1\end{array}$ & $\begin{array}{l}\text { Case } \\
\text { series }\end{array}$ & $\begin{array}{l}\text { After two weeks of ixekizumab injection, PASI score } \\
\text { improved from } 36 \text { to } 5 \text {. The other one achieved } \\
\text { PASI } 100 \text { after } 4 \text { doses of secukinumab. }\end{array}$ & None \\
\hline Ixekizumab & Lo et al ${ }^{106}(2019)$ & 9 & $\begin{array}{l}\text { Case } \\
\text { series }\end{array}$ & 4 (44\%) Patients achieved PASI 75 at week 12. & $\begin{array}{l}4(44.4 \%) \text { Patients with } \\
\text { injection site reaction. }\end{array}$ \\
\hline Ixekizumab & Lo et $\mathrm{al}^{107}(202 \mathrm{I})$ & 14 & $\begin{array}{l}\text { Case } \\
\text { series }\end{array}$ & $\begin{array}{l}\text { After } 52 \text { weeks, three }(21.4 \%) \text { patients achieved } \\
\text { PASI } 75 .\end{array}$ & $\begin{array}{l}5(35.7 \%) \text { Patients with } \\
\text { injection site reaction. } \\
\text { I patient with } \\
\text { vulvovaginal candidiasis. }\end{array}$ \\
\hline Brodalumab & $\begin{array}{l}\text { Yamasaki et al }{ }^{108} \\
(2017)\end{array}$ & 18 & $\begin{array}{l}\text { Case } \\
\text { series }\end{array}$ & $\begin{array}{l}\text { After week } 12,14(77.8 \%) \text { patients achieved PASI } \\
75,9(50 \%) \text { patients achieved PASI } 90 \text {, and } 3(16.7 \%) \\
\text { patients achieved PASI 100. At week 52, } 88.9 \% \text {, } \\
88.9 \% \text {, and } 61.1 \% \text { achieved PASI } 75 \text {, PASI } 90 \text {, and } \\
\text { PASI } 100 .\end{array}$ & Nasopharyngitis \\
\hline
\end{tabular}


Table 4 (Continued).

\begin{tabular}{|l|l|l|l|l|l|}
\hline $\begin{array}{l}\text { Biologic } \\
\text { Agent }\end{array}$ & Targets & \multicolumn{4}{|l|}{ Characteristics } \\
\hline Brodalumab & $\begin{array}{l}\text { Bernardini et al } \\
(2020)\end{array}$ & 1 & $\begin{array}{l}\text { Case } \\
\text { report }\end{array}$ & At week 4, PASI score decreased from 42 to 22. & None \\
\hline Brodalumab & Megna et al & & & \\
\hline 1020$)$ & 2 & $\begin{array}{l}\text { Case } \\
\text { series }\end{array}$ & $\begin{array}{l}\text { One case achieved PASI } 90 \text { at week 3. } \\
\text { One case achieved PASI } 90 \text { at week } 12 .\end{array}$ & None \\
\hline
\end{tabular}

Abbreviations: EP, erythrodermic psoriasis; IL, interleukin; IL-I7R, interleukin-I7 receptor; NR, not reported; PASI, Psoriasis Area and Severity Index.

Table 5 Other Treatment in EP Patients

\begin{tabular}{|c|c|c|c|c|c|}
\hline Treatment & Author (Year) & $\begin{array}{l}\text { Number } \\
\text { of } \\
\text { Subjects }\end{array}$ & $\begin{array}{l}\text { Study } \\
\text { Design }\end{array}$ & Results & $\begin{array}{l}\text { Adverse } \\
\text { Events }\end{array}$ \\
\hline Apremilast & Papadavid et al ${ }^{111}$ (2017) & I & $\begin{array}{l}\text { Case } \\
\text { report }\end{array}$ & $\begin{array}{l}\text { Achieved PASI } 100 \text { at } 20 \text { days. } \\
\text { Relapse after week } 12 .\end{array}$ & None \\
\hline Apremilast & $\begin{array}{l}\text { Krishnamoorthy et al } \\
(2019)\end{array}$ & I & $\begin{array}{l}\text { Case } \\
\text { report }\end{array}$ & $\begin{array}{l}\text { Achieved PASI } 100 \text { at week } 10 . \\
\text { Remained free of psoriasis for I year. }\end{array}$ & None \\
\hline Apremilast & Arcilla et al ${ }^{113}(2016)$ & 1 & $\begin{array}{l}\text { Case } \\
\text { report }\end{array}$ & NR & $\begin{array}{l}\text { Atrial } \\
\text { fibrilliation }\end{array}$ \\
\hline Apremilast & Mugheddu et al ${ }^{1 / 4}$ (2020) & I & $\begin{array}{l}\text { Case } \\
\text { report }\end{array}$ & NR & None \\
\hline Naltrexone & $\begin{array}{l}\text { Beltran Monasterio et } \mathrm{al}^{115} \\
(2019)\end{array}$ & I & $\begin{array}{l}\text { Case } \\
\text { report }\end{array}$ & $\begin{array}{l}\text { Achieved complete remission after } 3 \text { months of } \\
\text { treatment. }\end{array}$ & None \\
\hline Panitumumab & Nishizawa et al ${ }^{116}(2012)$ & I & $\begin{array}{l}\text { Case } \\
\text { report }\end{array}$ & Erythrodermic status improved after 10 days of treatment. & None \\
\hline $\begin{array}{l}\text { Coenzyme } \\
\text { QI0 } \\
+ \text { vitamin } \\
\text { E + selenium }\end{array}$ & Kharaeva et al ${ }^{117}$ (2009) & $\begin{array}{l}7 \\
7 \text { (placebo } \\
\text { group) }\end{array}$ & $\mathrm{RCT}$ & $\begin{array}{l}\text { After treatment for } 30 \text { days, PASI scores for the } \\
\text { supplement group were } 19 \pm 4 \text { compared to } 30 \pm 5 \text { in the } \\
\text { placebo group }(p<0.05)\end{array}$ & None \\
\hline
\end{tabular}

Abbreviations: EP, erythrodermic psoriasis; NR, not reported; PASI, Psoriasis Area and Severity Index; RCT, randomized controlled trial.

response was also not documented. Patients with EP usually tolerated MTX well, ${ }^{18,20-22,24}$ and nausea and vomiting were the most commonly reported adverse events; however, hepatotoxicity, hematologic and metabolic complications should be monitored. ${ }^{24,25}$

\section{Cyclosporine}

Cyclosporine is an immunosuppressive medication that blocks IL-2 transcription and results to inhibiting the growth of T-cell and proliferation. ${ }^{26}$ Several case reports and studies revealed the efficacy of cyclosporine for EP. ${ }^{22,27-37}$ The reported dosing of cyclosporine ranged from 1.5 to $5 \mathrm{mg} / \mathrm{kg} /$ day. ${ }^{27-29,34}$ The largest study is one open-label, single-center study from Italy which had $22(66.7 \%)$ patients in complete remission, with the initial mean dose of $4.2 \mathrm{mg} / \mathrm{kg} / \mathrm{day}$, and tapered by $0.5 \mathrm{mg} / \mathrm{kg}$ every 2 weeks. ${ }^{27}$ Ninety-four percent of the patients responded to the treatment according to the study, ${ }^{27}$ and approximately $2-4$ months were needed to achieve the treatment outcome. A faster treatment response seen within 1 month was reported for a combination treatment of cyclosporine and etretinate. ${ }^{33-35}$ Combination therapies with other treatment modalities were also reported, including $\mathrm{MTX}^{22}$ alefacept $^{32}$ etretinate $^{33-35}$ and phototherapy. ${ }^{36}$ One case series reported three cases with 
rapid response under cyclosporine and etretinate, achieving complete remission after combination treatment for 11-18 days, and with no signs of relapse during 1 year of followup. ${ }^{34}$ However, one case series reported failure to control in three patients with acitretin and cyclosporine. ${ }^{38}$ Cyclosporine is usually well-tolerated, though side effects including gastrointestinal upset, ${ }^{37}$ hypertension ${ }^{37}$ and acute kidney injury were reported. ${ }^{39}$ Clinicians should avoid using cyclosporine in elderly patients with hypertension or impaired renal function. ${ }^{1}$ Cyclosporine is considered a first-line therapy for acute and unstable cases according to the published consensus of the US National Psoriasis Foundation in $2010 .{ }^{1}$

\section{Acitretin/Etretinate}

Both etretinate and its active metabolite acitretin are often used for the treatment of $\mathrm{EP},{ }^{33-35,37,40-45,47}$ but the results have been inconsistent. Kim et al reported satisfactory outcomes for 12 patients with a monotherapy of acitretin, ${ }^{40} 10 \quad(83.3 \%)$ patients reported remission under the initial dose of $20-60 \mathrm{mg}$ daily. The average time to complete clearing of erythematous scales was 19.9 days, and the duration of clearing of erythema ranged from 2 to 11 months. However, Charbit et al reported two patients who failed to achieve greater than 50\% clearance after 3 months of treatment, $^{37}$ and in the report by Rosińska et al, only two of five children showed favorable results after treatment of one to 4 months of etretinate. ${ }^{41}$ Combination therapies with other immunosuppressive medication were common, including cyclosporine, ${ }^{37}$ acitretin with azathioprine, $^{43}$ or infliximab, ${ }^{44}$ and etretinate with cyclosporine $^{33-35}$ or MTX. ${ }^{42}$ One patient with EP coexisting with bullous pemphigoid was treated successfully with acitretin and azathioprine. ${ }^{43}$ Acitretin and MTX are considered more suitable for stable cases, compared to infliximab and cyclosporine, ${ }^{1}$ but due to the possible hepatotoxicity, this combination should be used cautiously. However, a case of EP caused by acitretin was reported. ${ }^{45}$ The use of a lower initial dose of acitretin reduced the risk of worsening erythrodermic status compared to higher dose. ${ }^{46}$ Cheilitis is the most common side effect under acitretin or etretinate. ${ }^{34,40}$ Gastrointestinal upset and elevated lipid profile levels ${ }^{42}$ should also be monitored. In addition, bone density should be checked as focal osteoporosis has been reported. $^{41}$

\section{Mycophenolate Mofetil (MMF)}

Limited evidence exists for successfully using MMF for treating EP. Only one case reported two patients treated with $\mathrm{MMF}^{48}$ and both of them experienced $70 \%$ skin improvement after 6 weeks of treatment. No adverse effects were observed during the treatment course, and the disease did not relapse after drug discontinuation.

\section{Tumor Necrosis Factor (TNF) Antagonist Etanercept}

Etanercept, a recombinant human fusion protein, has demonstrated efficacy in treating EP. ${ }^{49-54}$ Esposito et al reported that with $25 \mathrm{mg}$ twice weekly, a treatment response could be observed between week 12-24. ${ }^{49}$ At week 12, five of ten (50\%) patients achieved PASI 75 , and at week 24 , six of ten $(60 \%)$ patients achieved or maintained PASI 75, and two of ten patients (20\%) maintained improvement between PASI 50 and PASI 75. PiquéDuran et al reported one case who achieved PASI 100 as early as week 9. ${ }^{50}$ Romero-Marte et al reported one case with stable condition under etanercept for 34 months after suboptimal response to infliximab. ${ }^{51}$ In a retrospective study, $50 \mathrm{mg}$ dosing twice weekly for 12 weeks, then $50 \mathrm{mg}$ weekly thereafter, $40 \%$ patients achieved PASI 50 at week $24-28 .{ }^{52}$ Infection is the most common side effect, with pneumonia, and Staphylococcus aureus septicemia and urinary infection being reported. ${ }^{49,52}$

\section{Infliximab}

Infliximab, a chimeric monoclonal antibody, is considered to be a first-line biologic for EP due to its rapid onset. $^{1,44,52,53,55-70}$ In one multicenter study that included 24 patients, ${ }^{52}$ one-third of the patients achieved PASI 75 at week 4 with infliximab treatment. But longterm efficacy is not so promising, as at the same study that only $48 \%$ of patients achieved PASI 75 at week $14,^{52}$ and one case reported no further improvement after the sixth infusion of infliximab; the subject's condition was then controlled by administration of etanercept. $^{51}$ The occurrence of the anti-infliximab antibody was considered to be the reason. ${ }^{55}$ Poulalhon et al reported the prevalence of positive detection of antinuclear antibodies (ANA) increased from $12 \%$ to $72 \%$ at week 22. ${ }^{55}$ Thus, the use of infliximab as long-term controlling medication for EP should be evaluated. Concurrent administration with immunosuppressive medication would induce rapid clearing of erythrodermic status, ${ }^{44,56,57}$ and MTX and acitretin are often used. 
Lisby et al and Heikkila et al reported rapid treatment responses with a combination treatment with MTX. ${ }^{56,57}$ Heikkila et al reported four $(100 \%)$ patients with excellent responses after the second or third infusion of infliximab combined with $\mathrm{MTX}^{56}$ and Lisby et al reported three $(100 \%)$ patients that almost clearance within a week after the first infusion of infliximab. ${ }^{57}$ The dosing of infliximab ranged from 2.7 to $4.4 \mathrm{mg}$ per $\mathrm{kg}$ and MTX with 5 to $7.5 \mathrm{mg}$ per week. ${ }^{57}$ Infection is the most common side effect, such as staphylococcus aureus septicemia, ${ }^{52,57}$ nasopharyngitis, ${ }^{60}$ and erysipelas. ${ }^{52,57}$ Moreover, delayed infusion reactions, ${ }^{55}$ myocardial infarction, suicide attempts and immunoallergic shock have also been reported after administration of infliximab. ${ }^{52}$ Furthermore, one case reported $\mathrm{CD} 30+\mathrm{T}$-cell lymphoma under the treatment of cyclosporine and infliximab, ${ }^{58}$ and the lesion regressed after discontinuation of these agents.

\section{Golimumab}

Golimumab, another anti-TNF, is a fully human $\gamma-1 \mathrm{immu}-$ noglobulin- $\kappa$ monoclonal antibody. The evidence of golimumab for treating EP is limited with only one report. ${ }^{71}$ After three sessions of golimumab $50 \mathrm{mg}$ injections every 4 weeks, the patient achieved PASI 75 without any side effects.

\section{Adalimumab}

Adalimumab is another fully human monoclonal antibody against TNF. There have been only nine patients receiving adalimumab for treatment, including one multicenter, retrospective study with seven patients, ${ }^{52}$ and two case reports. ${ }^{72,73}$ Most data are from the retrospective study which revealed that $67 \%$ of the patients achieved PASI 75 at week 10 to 14 , and at week 22 to $24,50 \%$ of the patients achieved PASI75 or $75 \%$ improvement in BSA, compared to $25 \%$ of the patients treated with etanercept and $30 \%$ of the patients treated with infliximab in that study. ${ }^{52}$ Richetta et al reported one case involving a hepatitis $\mathrm{C}$ virus (HCV) flare-up after treatment with pegylated interferon alpha-2a and ribavirin. The symptoms were controlled by adalimumab at week 3, and no adverse effects were observed during the 5 weeks of treatment. ${ }^{73}$ One patient was diagnosed with nodal T-cell lymphoma 3 months later after administration of adalimumab. ${ }^{52}$ Paradoxically, there are also reports regarding adalimumab as a trigger of EP. ${ }^{74}$

\section{IL-12/23, IL-23 Antagonist Ustekinumab}

Ustekinumab, a monoclonal p40 IL-12/23 antagonist, has been reported for treatment of EP in several articles. ${ }^{75-85}$ The largest study was from Italy, ${ }^{75}$ which include 22 patients. As early as week 4, most of the patients had improved clinical condition, 15 (68.2\%) patients achieved PASI 90 at week 28, and sustained effects were seen at week 60. Additionally, Wang et al reported suboptimal treatment effects: at week 28 , only $3(37.5 \%)$ patients achieved PASI $90 .^{77}$ Ustekinumab has also been reported as effective for cases of prior failure with anti-TNF agents, ${ }^{76,82-84}$ and one case reported sustained maintained PASI 90 at week 114 of treatment. ${ }^{84}$ However, Viguier et al reported three cases under the treatment of ustekinumab, in which only one (33.3\%) had treatment response, ${ }^{52}$ with the other two patients experiencing inadequate response to prior anti-TNF agents. Ustekinumab is also considered as a first-line treatment for acute and severe cases of EP. ${ }^{70}$ Although ustekinumab is considered to have a relative low risk of infection compared to anti-TNF agents, a case of latent TB reactivation induced by ustekinumab has been reported. ${ }^{86}$ One adverse event of sudden death was reported after 9 months of treatment of ustekinumab. $^{52}$ Furunculosis and widespread Staphylococcus infection have been observed. ${ }^{52}$

\section{Guselkumab}

Guselkumab, an interleukin 23 inhibitor that targets the p19 subunit, was reported as effective for EP in 24 cases. In an open-label, multicenter, Phase 3 study $^{87}(50 \mathrm{mg}$ at weeks 0,4 and every 8 weeks thereafter until week 52), 10 $(90.9 \%)$ patients achieved treatment success, while 5 (45.5\%) patients achieved "very much improved" under Clinical Global Impression of Improvement (CGI). At week 52, 10 (90.9\%) patients achieved a mean absolute PASI of $3.9(\mathrm{SD}=4.27)$ with a median improvement of 94.1\%. Megna et al reported one patient achieved PASI 100 after 20 weeks of therapy, and the effect remained until week $48{ }^{88}$ Chiang et al reported 13 patients with follow-up for 28 weeks, ${ }^{89}$ in which 8 (61.5\%) patients achieved PASI 50 response at week 12, and sustained effects were observed for these PASI 50 responders. The treatment efficacy at week 12 could be seen as one predictor for patient response for guselkumab. ${ }^{89}$ The most common adverse event was nasopharyngitis. ${ }^{87}$ 


\section{Risankizumab}

Risankizumab is another IL-23 antagonist that targets the p19 subunit. One phase 3 open-label clinical trial has been completed in Japanese patients with pustular psoriasis or $\mathrm{EP},{ }^{90}$ dosing with $75 \mathrm{mg}$ at week 0 , week 4 , and every 12 weeks. At week 16, the clinical response was $100 \%$, and all of the patients achieved PASI 90.

\section{IL-I7 Antagonist}

\section{Secukinumab}

Secukinumab, a fully human monoclonal IL-17A antibody, is administered at a dose of $300 \mathrm{mg}$ weekly for the first 5 weeks and every 4 weeks thereafter for the treatment of EP. ${ }^{91-101}$ The efficacy of secukinumab can be seen as early as week 2 to week $6 .^{92-94}$ Mateu-Puchades et al reported 5 $(100 \%)$ patients achieved PASI 90 at week 16 to week $20{ }^{93}$ Furthermore, long-term remission was observed for patients with EP under secukinumab. ${ }^{96,97,100,101}$ One multicenter, retrospective study reported 10 of 13 (76.9\%) patients had a treatment response. ${ }^{98}$ At week 52, 5 (38.5\%) patients achieved PASI 90 and 5 patients achieved PASI 100 , and the median time to clearance was 3 weeks. ${ }^{98}$ No recurrences were seen during the 52 weeks follow-up. ${ }^{98}$ However, Weng et al reported that only $6 / 10$ patients $(60 \%)$ achieved PASI 75 response at week 24 possibly because most of the patients had failed with multiple biologics previously. ${ }^{91}$ No major events were observed during treatment course. ${ }^{91-93}$

\section{Ixekizumab}

Ixekizumab, another IL-17A blocker, demonstrated a sustained effect for EP according to a study from Japan. ${ }^{102,103}$ In an open-label, phase 3 study, eight patients were enrolled (dosed $160 \mathrm{mg}$ at week $0,80 \mathrm{mg}$ every 2 weeks through week 12 , and $80 \mathrm{mg}$ every 4 weeks until to week 244). ${ }^{102,103}$ Eight (100\%) patients achieved PASI 75 after 12 weeks of treatment, all patients maintained PASI 75 at week 24 and week 52, and $6(75 \%)$ patients achieved PASI $90 .{ }^{102}$ The results revealed that the effects were sustained to week 244, the mean PASI score was 42.8 at baseline, 3.0 at week 52, and 5.0 at week 244 . There are also several case reports regarding the efficacy of ixekizumab for EP, ${ }^{104-106}$ including one case with human immunodeficiency virus (HIV) infection. ${ }^{106}$ For patients with prior failure with secukinumab, ixekizumab still demonstrated a rapid response as early as week $4 .{ }^{107}$ Suboptimal responses were reported in only four (44\%) patients, who achieved PASI 75 at week 12 according to a previous study. In addition, the response was even poorer after prolonged use. ${ }^{108}$ After week 52, the discontinuation rate increased, only three (21.4\%) patients achieved PASI 75 , and one (7.1\%) patient achieved PASI 90. Infection was a common side effect, ${ }^{103}$ including upper respiratory tract infection and gastroenteritis. Injection-site swelling was also observed in about $30 \%$ of the cases. ${ }^{107,108}$

\section{Brodalumab}

Brodalumab, an anti-IL-17-receptor antibody, also demonstrated efficacy for EP.

There is one open-label study and two case reports discussing the treatment of brodalumab. ${ }^{109-111}$ During a 52week, phase 3, multicenter, open-label study, ${ }^{109}$ with brodalumab 140mg twice weekly subcutaneous administration initially (week 0 , week 1 , week 2 ), 5 (27.8\%) patients were shifted to receive $210 \mathrm{mg}$ based on the investigators' decision. Eighteen (100\%) patients showed clinical improvement, under the definition of achieving CGI classified as "improved" or "remission" at week 12 and week 52. Sustainable effects were observed through week 52, PASI 75 and PASI 90 achievement rates were both $88.9 \%$, while the PASI 100 response was $61.1 \%$. Bernardini et al reported one case with EP and polycythemia, ${ }^{110}$ and the PASI score improved from 42 to 22 within 4 weeks of treatment with brodalumab. Megna et al reported two cases successfully treated with EP, one achieved PASI 90 at week 3 and reached PASI 100 at week 12, and the other one achieved PASI 90 at week $12 .{ }^{111}$ Patients usually tolerated brodalumab well without major adverse events, ${ }^{110,112}$ The most common adverse event was nasopharyngitis. ${ }^{109}$

\section{Others}

\section{Apremilast}

Apremilast, a phosphodiesterase 4 (PDE4) inhibitor, has been used for EP in four case reports. ${ }^{112-115}$ Papadavid et al reported one case of a previous failure with MTX, cyclosporine and adalimumab, who achieved PASI 100 after apremilast $30 \mathrm{mg}$ twice daily for 20 days. ${ }^{112}$ Krishnamoorthy et al reported one case with the total resolution of the lesions after 10 weeks of treatment without relapse for 1 year. ${ }^{113}$ Another case was infected with coronavirus 2019 (COVID-19) and was treated successfully with apremilast for EP. ${ }^{115}$ Apremilast may also be effective for elderly EP patient, according to one retrospective study. ${ }^{116}$ Papadavid et al reported gradual deterioration of the absolute PASI score after 4 months of treatment. ${ }^{112}$ Infection is still one of the common side 
effects as one case experienced two episodes of upper respiratory infection during the treatment with apremilast. ${ }^{113}$ Furthermore, one major adverse event was atrial fibrillation induced by apremilast. ${ }^{114}$

\section{Naltrexone}

Naltrexone, which affects the opioid growth factor-opioid growth factor receptor, also plays a role in the immune system. Beltran Monasterio et al reported after oral low-dose naltrexone with a daily dose of $4.5 \mathrm{mg}$ for 3 months, the patient remained complete remission after 6 months of treatment. ${ }^{117}$

\section{Panitumumab}

Panitumumab is a human monoclonal antibody against EGFR, and was reported to have some clinical effect for psoriasis in one patient with rectal cancer. ${ }^{118}$ The patient had improved clinical condition within 10 days of treatment with panitumumab, although no PASI score was reported.

\section{Antioxidants}

In one randomized controlled trial, coenzyme Q10, vitamin E, and selenium supplementation were beneficial for EP. ${ }^{119}$ Clinical conditions improved with supplementation of antioxidants. After treatment for 30 days, PASI score was $19 \pm 4$ for the supplement group and $30 \pm 5$ for the placebo group $(\mathrm{p}<0.05)$. Due to a lack of further studies, the evidence for using antioxidants for EP has been called into question.

\section{Systemic Steroid}

Systemic steroid is not recommended according to the published consensus of the US National Psoriasis Foundation in 2010. ${ }^{1}$ However, the use of systemic steroid for treatment of psoriasis may be more common than expected in real world but is highly controversial. Exacerbation of erythrodermic status after withdrawal or reduction of systemic corticosteroid has been well documented, ${ }^{2}$ but it may be uncommon as reported in some recent studies. ${ }^{120,121}$ Anecdotal reports showed improvement of EP following systemic steroid. ${ }^{86,122}$ Short course systemic steroid, combined with conventional immunosuppressive agents, can be considered for acute cases $^{122}$ who are not accessible or contraindicated to biologics or cyclosporine.

\section{Phototherapy}

Phototherapy is not suggested for acute EP, due to the photosensitization can increase the risk of Koebnerization. ${ }^{1,2}$ But phototherapy can still be considered as one of the treatment options for long-term, stable EP cases. ${ }^{1}$ Some case reported phototherapy as adjunctive therapy for EP. ${ }^{123,124}$ Pang et al reported one case with phototherapy as adjunctive therapy who was refractory to acitretin. ${ }^{123}$

\section{Discussion}

EP is a variant of psoriasis that is more resistant to conventional treatment. Biologics have revolutionized the treatment of plaque-type psoriasis, and shown promise in EP. ${ }^{70,125,126}$ Anti-TNF agents, such as infliximab and etanercept can be combined with traditional immunosuppressive agents for better efficacy, ${ }^{125}$ while anti-IL12/23 agents and anti-IL17 agents are usually given as monotherapy for EP due to their superior efficacy, and are therefore used as first-line treatments for EP, including ustekinumab, secukinumab, ixekizumab, guselkumab and brodalumab. ${ }^{70,125,126}$ In particular, anti-IL17 agents can

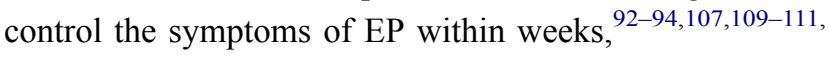
which may be considered in patients who need rapid control. Furthermore, an ongoing trial for risankizumab revealed promising results for 16 weeks, ${ }^{90}$ but the longerduration efficacy remains to be published.

However, there is evidence supporting the efficacy of biologics for treating EP in case reports and case-series, albeit they often lack long-term follow up data. In pivotal trials of biologics for psoriasis, current or even prior EP have been excluded for the study. ${ }^{127}$ Even in countries that issue indications for use of biologics for EP, such as Japan, the number of patients in the trials have been severely limited, 8 for infliximab, ${ }^{60} 8$ for ixekizumab, ${ }^{102} 11$ for guselkumab, ${ }^{87}$ and 18 for brodalumab. ${ }^{109}$ Moreover, none of the trials were randomized active or placebo controlled trials. Among the biologics, fewer major adverse events were reported for anti-IL12/23 agents and anti-IL17 agents than anti-TNF agents, and infection remains the most common side effect which should be monitored. Interestingly, according to a previous study, ${ }^{128}$ in biologicnaïve patients with psoriasis or psoriatic arthritis, antiIL12/23 agents were associated with a reduced risk of infection compared to anti-TNF and anti-IL-17 agents. However, there is no difference in infection risk in either of these agents in patients with prior biologic use. Whether the result can be applied to EP patients awaits further studies. In addition, it is also important to consider the comorbidities during the treatment of EP. ${ }^{2}$ Several articles reported EP triggered by infection, such as HCV and HIV infection. ${ }^{47,73,106}$ Although biologics are considered safer 


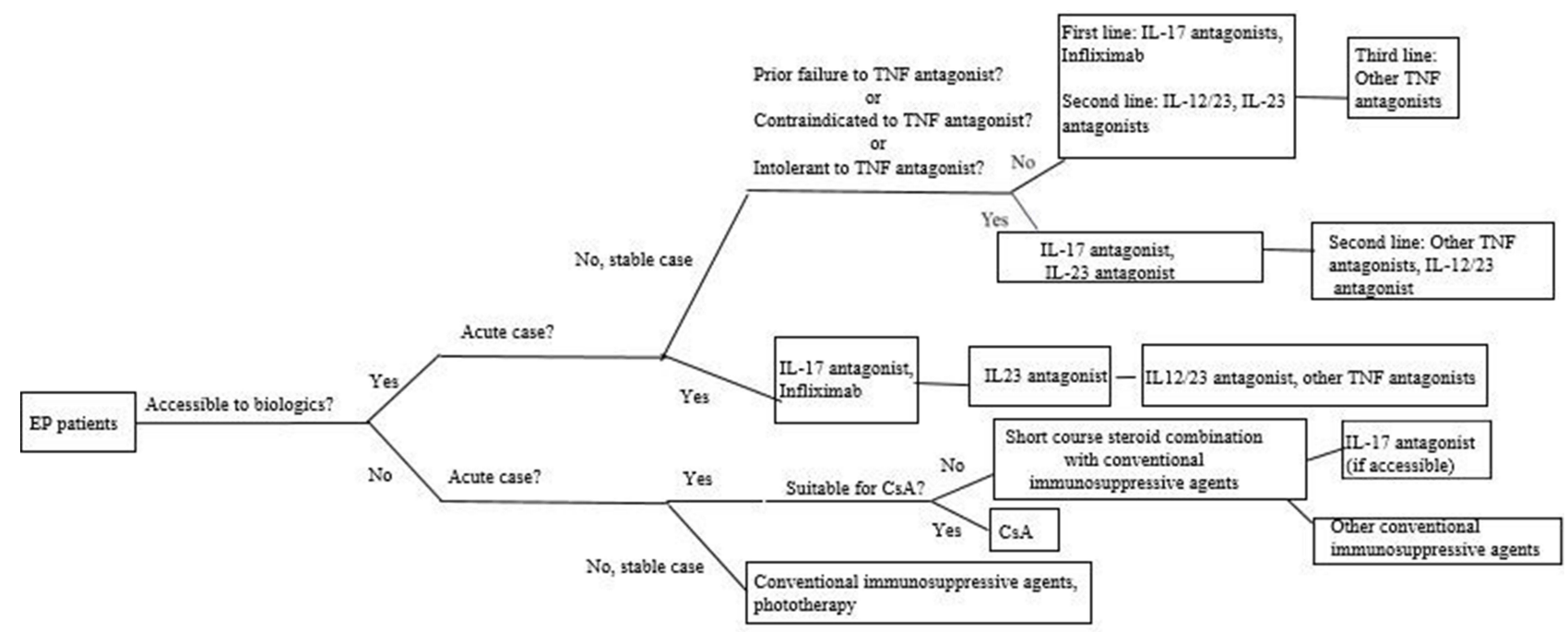

Figure I Treatment algorithm of EP, suggested by the author.

Abbreviations: CsA, cyclosporine; EP, erythrodermic psoriasis; IL, interleukin; TNF, tumor necrosis factor.

agents compared to conventional oral agents, their use in patients with viral hepatitis and HIV remains limited.

Drug survival is impaired in EP compared to plaque-type psoriasis in post-marketing studies. Thus, patients with EP treated with biologics tend to have multiple experiences of prior biologics failure, which will also compromise subsequent treatment efficacy. ${ }^{129}$ In general, patients achieved better efficacy after switching to IL-23 and IL-17 antagonists after previous poor response to anti-TNF agents and ustekinumab. ${ }^{130}$ However, in patients with prior inadequate response to secukinumab, ${ }^{107,108}$ the results were poorer than the open-label, phase 3 study after the switch to ixekizumab. ${ }^{103}$ Interestingly, although the efficacy of small oral molecules is less satisfactory compared to biologics in the treatment of psoriasis, two promising results of using apremilast were reported in $\mathrm{EP}^{112,113}$; however, the case numbers were small. Likewise, tofacitinib has been reported to be effective in patients with moderate to severe psoriasis who had inadequate responses to prior biologics. ${ }^{131}$ However, its role in EP remains unknown. Further head-to head controlled studies are needed for more evidence-based treatment guidelines.

For patients who have no access to biologics, conventional immunosuppressive agents are suggested. Cyclosporine is suggested for acute cases, and others for stable cases. ${ }^{1}$ Short course systemic corticosteroid should be reserved for EP patients during severe acute flare who do not has access to biologics and are contraindicated to cyclosporine due to uncontrolled hypertension or renal insufficiency or malignancy. Even in these patients, adequate hydration and aggressive control of hypertension should be attempted to enable the use of cyclosporine. However, the optimal dose and duration of systemic corticosteroid use is unknown. Transition and/or overlap to a non-systemic corticosteroid regimen should be initiated once the acute flare is controlled. Preferably, a fast onset biologic such as IL-17 inhibitor should be given to prevent the rebound/flare of psoriasis after corticosteroid withdrawal. However, gradual corticosteroid taper may be needed if conventional oral agents or phototherapy are used. We propose the algorithm for treatment of EP after literature review (Figure 1).

\section{Conclusion}

Despite the rapid progress in the development of biologics for psoriasis, data supporting the efficacy in EP remain limited. Also, the remission duration and risk of rebound upon discontinuation are poorly studied. In addition, it is important to understand the drug survival time, optimal dosing, and pharmacokinetics of biologics for EP.

\section{Funding}

There is no funding to report.

\section{Disclosure}

Dr Tsen-Fang Tsai has conducted clinical trials and/or received honoraria for serving as a consultant for AbbVie, Boehringer Ingelheim, Bristol Myers Squibb, Celgene, EliLilly, Galderma, GSK-Stiefel, Janssen-Cilag, LeoPharma, Merck Sharp \& Dohme, Novartis, Pfizer and Serono International SA (now Merck Serono 
International). Dr Yang Lo has no conflicts of interest to declare.

\section{References}

1. Rosenbach M, Hsu S, Korman NJ, et al. Treatment of erythrodermic psoriasis: from the medical board of the National Psoriasis Foundation. $J$ Am Acad Dermatol. 2010;62(4):655-662. doi:10.1016/j.jaad.2009.05.048

2. Boyd AS, Menter A. Erythrodermic psoriasis. Precipitating factors, course, and prognosis in 50 patients. J Am Acad Dermatol. 1989;21(5 Pt 1):985-991. doi:10.1016/S0190-9622(89)70287-5

3. Yan D, Afifi L, Jeon C, Cordoro KM, Liao W. A cross-sectional study of the distribution of psoriasis subtypes in different ethno-racial groups. Dermatol Online J. 2018;24(7):13030/ qt5z21q4k2.

4. Chen HS, Tseng MP, Tsai TF. An epidemiologic study of Taiwanese psoriatic patients in a single clinic. Dermatol Sinica. 2003;21(3):216-224.

5. Stinco G, Errichetti E. Erythrodermic psoriasis: current and future role of biologicals. BioDrugs. 2015;29(2):91-101. doi:10.1007/ s40259-015-0119-4

6. Lo Y, Chiu HY, Tsai TF. Clinical Features and Genetic Polymorphism in Chinese Patients with Erythrodermic Psoriasis in a Single Dermatologic Clinic. Mol Diagn Ther. 2020;24 (1):85-93. doi:10.1007/s40291-019-00441-x

7. Zhang P, Chen H, Duan Y, et al. Analysis of Th1/Th2 response pattern for erythrodermic psoriasis. J Huazhong Univ Sci Tech Med Sci. 2014;34(4):596-601. doi:10.1007/s11596-014-1322-0

8. Li L-F, Sujan SA, Yang H, Wang W-H. Serum immunoglobulins in psoriatic erythroderma. Clin Exp Dermatol. 2005;30 (2):125-127. doi:10.1111/j.1365-2230.2004.01717.x

9. Deeva I, Mariani S, De Luca C, et al. Wide-spectrum profile of inflammatory mediators in the plasma and scales of patients with psoriatic disease. Cytokine. 2010;49(2):163-170. doi:10.1016/j. cyto.2009.09.014

10. Groves RW, Kapahi P, Barker JN, Haskard DO, MacDonald DM. Detection of circulating adhesion molecules in erythrodermic skin disease. J Am Acad Dermatol. 1995;32(1):32-36.

11. Moy AP, Murali M, Kroshinsky D, Duncan LM, Nazarian RM. Immunologic Overlap of Helper T-Cell Subtypes 17 and 22 in Erythrodermic Psoriasis and Atopic Dermatitis. JAMA Dermatol. 2015;151(7):753-760. doi:10.1001/jamadermatol.2015.2

12. Wang $\mathrm{H}$, Wang $\mathrm{S}, \mathrm{Li} \mathrm{L}$, et al. Involvement of the cytokine TWEAK in the pathogenesis of psoriasis vulgaris, pustular psoriasis, and erythrodermic psoriasis. Cytokine. 2020;138:155391. doi:10.1016/j.cyto.2020.155391

13. Zheng J, Gao Y, Liu N, et al. Higher prevalence of thyroid dysfunction in patients with erythrodermic psoriasis. $J \quad$ Dermatol. 2020;47(9):1007-1012. doi:10.1111/13468138.15427

14. Chen L, Tsai TF. HLA-Cw6 and psoriasis. Br J Dermatol. 2018;178(4):854-862. doi:10.1111/bjd.16083

15. Henseler T, Koch F, Westphal E. Presence of HLA- DR7 in type I psoriasis. J Invest Dermatol. 1992;98(4):607.

16. Mallon E, Bunce M, Savoie H, et al. HLA-C and guttate psoriasis. Br J Dermatol. 2000;143(6):1177-1182. doi:10.1046/ j.1365-2133.2000.03885.x

17. Signa S, Campione E, Rusmini M, et al. Whole exome sequencing approach to childhood onset familial erythrodermic psoriasis unravels a novel mutation of CARD14 requiring unusual high doses of ustekinumab. Pediatr Rheumatol Online J. 2019;17 (1):38. doi:10.1186/s12969-019-0336-3
18. Collins P, Rogers S. The efficacy of methotrexate in psoriasis-a review of 40 cases. Clin Exp Dermatol. 1992;17(4):257-260. doi:10.1111/j.1365-2230.1992.tb02161.x

19. Van Dooren-greebe RJ, Kuijpers AL, Mulder J, De Boo T. Methotrexate revisited: effects of long-term treatment in psoriasis. Br J Dermatol. 1994;130(2):204-210. doi:10.1111/ j.1365-2133.1994.tb02901.x

20. Haustein UF, Rytter M. Methotrexate in psoriasis: 26 years' experience with low-dose long-term treatment. $J$ Eur Acad Dermatol Venereol. 2000;14(5):382-388. doi:10.1046/j.14683083.2000.00058.x

21. Kumar B, Dhar S, Handa S, Kaur I. Methotrexate in childhood psoriasis. Pediatr Dermatol. 1994;11(3):271-273. doi:10.1111/ j.1525-1470.1994.tb00602.x

22. Aydin F, Canturk T, Senturk N, Turanli AY. Methotrexate and ciclosporin combination for the treatment of severe psoriasis. Clin Exp Dermatol. 2006;31(4):520-524. doi:10.1111/j.13652230.2006.02153.x

23. Khaled A, Ben Hamida M, Zeglaoui F, Kharfi M, Ezzine N, Fazaa B. Traitement du psoriasis par méthotrexate à l'ère des biothérapies: étude chez 21 patients tunisiens [Treatment of psoriasis by methotrexate in the era of biotherapies: a study in 21 Tunisian patients]. Therapie. 2012;67(1):49-52. doi:10.2515/therapie/2012004

24. Hawilo A, Zaraa I, Benmously R, et al. Erythrodermic psoriasis: epidemiological clinical and therapeutic features about 60 cases. Tunis Med. 2011;89(11):841-847.

25. Mahmood T, Zaghi D, Menter A. Emerging oral drugs for psoriasis. Expert Opin Emerg Drugs. 2015;20(2):209-220. doi:10.1517/14728214.2015.1010509

26. Lim KK, Su WP, Schroeter AL, Sabers CJ, Abraham RT, Pittelkow MR. Cyclosporine in the treatment of dermatologic disease: an update. Mayo Clin Proc. 1996;71(12):1182-1191. doi: $10.4065 / 71.12 .1182$

27. Studio Italiano Multicentrico nella Psoriasi (SIMPSO). Management of erythrodermic psoriasis with low-dose cyclosporine. Dermatology. 1993;187(Suppl 1):30-37. doi:10.1159/000247289

28. Bruzzese V, Pepe J. Efficacy of cyclosporine in the treatment of a case of infliximab-induced erythrodermic psoriasis. Int J Immunopathol Pharmacol. 2009;22(1):235-238. doi:10.1177/039463200902200126

29. Ahdout J, Mandel H, Chiu M. Erythroderma in a patient taking acitretin for plaque psoriasis. J Drugs Dermatol. 2008;7 (4):391-394.

30. Sprecher E, Bergman R, Friedman-Birnbaum R. Cyclosporine treatment of psoriatic erythroderma complicated by bacterial sepsis. J Eur Acad Dermatol Venereol. 1999;12(2):197-198. doi:10.1111/j.1468-3083.1999.tb01027.x

31. Borghi A, Corazza M, Mantovani L, Bertoldi AM, Giari S, Virgili A. Prolonged cyclosporine treatment of severe or recalcitrant psoriasis: descriptive study in a series of 20 patients. Int $J$ Dermatol. 2012;51(12):1512-1516. doi:10.1111/j.13654632.2012.05571.x

32. Prossick TA, Belsito DV. Alefacept in the treatment of recalcitrant palmoplantar and erythrodermic psoriasis. Cutis. 2006;78 (3):178-180.

33. Brechtel B, Wellenreuther U, Toppe E, Czarnetski BM. Combination of etretinate with cyclosporine in the treatment of severe recalcitrant psoriasis. J Am Acad Dermatol. 1994;30 (6):1023-1024. doi:10.1016/S0190-9622(09)80147-3

34. Kokelj F, Plozzer C, Torsello P, Trevisan G. Efficacy of cyclosporine plus etretinate in the treatment of erythrodermic psoriasis (three case reports). J Eur Acad Dermatol Venereol. 1998;11 (2):177-179. 
35. Korstanje MJ, Bessems PJ. Combination therapy ciclosporin-etretinate effective in erythrodermic psoriasis. Dermatologica. 1989;179(2):94. doi:10.1159/000248324

36. Franchi C, Cainelli G, Frigerio E, Garutti C, Altomare GF. Association of cyclosporine and $311 \mathrm{nM}$ UVB in the treatment of moderate to severe forms of psoriasis: a new strategic approach. Int J Immunopathol Pharmacol. 2004;17(3):401-406. doi: $10.1177 / 039463200401700321$

37. Charbit L, Mahé E, Phan A, et al. Systemic treatments in childhood psoriasis: a French multicentre study on 154 children. $\mathrm{Br}$ J Dermatol. 2016;174(5):1118-1121. doi:10.1111/bjd.14326

38. Kuijpers ALA, van Dooren-greebe RJ. Failure of combination therapy with acitretin and cyclosporine $\mathrm{A}$ in 3 patients with erythrodermic psoriasis. Dermatology. 1997;194(1):88-90. doi: $10.1159 / 000246070$

39. Rao S, Bernshteyn M, Sohal R, Proumen R, Goodman A, Shepherd Z. The Management of Erythrodermic Psoriasis Complicated by Cyclosporine. Case Rep Dermatol Med. 2020;2020:5215478. doi:10.1155/2020/5215478

40. Kim BS, Shin KS, Youn JI, Lee YS. Treatment of erythrodermic psoriasis with etretinate. Ann Dermatol. 1991;3(2):107-111. doi:10.5021/ad.1991.3.2.107

41. Rosińska D, Wolska H, Jablonska S, Konca I. Etretinate in severe psoriasis of children. Pediatr Dermatol. 1988;5(4):266. doi:10.1111/j.1525-1470.1988.tb00902.x

42. Tuyp E, MacKie RM. Combination therapy for psoriasis with methotrexate and etretinate. J Am Acad Dermatol. 1986;14 (1):70-73. doi:10.1016/S0190-9622(86)70009-1

43. Roeder C. Psoriatic erythroderma and bullous pemphigoid treated successfully with acitretin and azathioprine. Eur $J$ Dermatol. 1999;9(7):537-539.

44. Takahashi MDF, Castro LG, Romiti R. Infliximab, as sole or combined therapy, induces rapid clearing of erythrodermic psoriasis. Br J Dermatol. 2007;157(4):828-831. doi:10.1111/ j.1365-2133.2007.08111.x

45. Ahdout J, Mandel H, Chiu M. Erythroderma in a patient taking acitretin for plaque psoriasis. J Drugs Dermatol. 2008;7:391.

46. Ling MR. Acitretin: optimal dosing strategies. J Am Acad Dermatol. 1999;41(3 Pt 2):S13-17. doi:10.1016/S0190-9622(99) 70360-9

47. Valenzuela F, Fernández J, Sánchez M, Zamudio A Erythrodermic psoriasis and human immunodeficiency virus: association and therapeutic challenges. An Bras Dermatol. 2018;93(3):438-440. doi:10.1590/abd1806-4841.20187387

48. Geilen CC, Tebbe B, Garcia Bartels C, Krengel S, Orfanos CE. Successful treatment of erythrodermic psoriasis with mycophenolate mofetil. $\mathrm{Br} \quad J$ Dermatol. 1998;138(6):1101-1102. doi:10.1046/j.1365-2133.1998.02296.x

49. Esposito M, Mazzotta A, de Felice C, Papoutsaki M, Chimenti S. Treatment of erythrodermic psoriasis with etanercept. $\mathrm{Br}$ $J \quad$ Dermatol. 2006;155(1):156-159. doi:10.1111/j.13652133.2006.07217.x

50. Pique-Duran E, Perez-Cejudo JA. Psoriatic erythroderma treated with etanercept. Actas Dermosifiliogr. 2007;98(7):508-510.

51. Romero-Maté A, García-Donoso C, Martinez-Morán C, Hernández-Núñez A, Borbujo J. Long-term management of erythrodermic psoriasis with anti-TNF agents. Dermatol Online J. 2010;16(6):15.

52. Viguier $M$, Pagès $C$, Aubin $F$, et al. Efficacy and safety of biologics in erythrodermic psoriasis: a multicentre, retrospective study. Br J Dermatol. 2012;167(2):417-423. doi:10.1111/j.13652133.2012.10940.x

53. Sahel H, Bouadjar B. Treatment of Erythrodermic Psoriasis with Infliximab and Etanercept in Two Cases. J Clinic Exper Cosme Derma. 2017;1:002.
54. Fraga NA, Paim Mde F, Follador I, Ramos AN, Rêgo VR Refractory erythrodermic psoriasis in a child with an excellent outcome by using etanercept. An Bras Dermatol. 2011;86(4 suppl 1):S144-S147. doi:10.1590/S0365-05962011000700038

55. Poulalhon N, Begon E, Lebbe C, et al. A follow-up study in 28 patients treated with infliximab for severe recalcitrant psoriasis: evidence for efficacy and high incidence of biological autoimmunity. $\mathrm{Br} \quad J \quad$ Dermatol. 2007;156(2):329-336. doi:10.1111/j.1365-2133.2006.07639.x

56. Lisby S, Gniadecki R. Infliximab (Remicade) for acute, severe pustular and erythrodermic psoriasis. Acta Derm Venereol. 2004;84(3):247-248.

57. Heikkila H, Ranki A, Cajanus S, Karvonen SL. Infliximab combined with methotrexate as long-term treatment for erythrodermic psoriasis. Arch Dermatol. 2005;141(12):1607-1610. doi:10.1001/ archderm.141.12.1607

58. Mahé E, Descamps V, Grossin M, Fraitag S, Crickx B. CD30+ T-cell lymphoma in a patient with psoriasis treated with ciclosporin and infliximab. $\mathrm{Br} J$ Dermatol. 2003;149(1):170-173. doi:10.1046/j.1365-2133.2003.05384.x

59. Rongioletti F, Borenstein M, Kirsner R, Kerdel F. Erythrodermic, recalcitrant psoriasis: clinical resolution with infliximab. $J$ Dermatol Treat. 2003;14(4):222-225. doi:10.1080/ 09546630310010895

60. Torii $\mathrm{H}$, Nakagawa $\mathrm{H}$, Japanese Infliximab Study Investigators Long-term study of infliximab in Japanese patients with plaque psoriasis, psoriatic arthritis, pustular psoriasis and psoriatic erythroderma. J Dermatol. 2011;38(4):321-334. doi:10.1111/ j.1346-8138.2010.00971.x

61. Lewis TG, Tuchinda C, Lim HW, Wong HK. Life-threatening pustular and erythrodermic psoriasis responding to infliximab. J Drugs Dermatol. 2006;5(6):546-548.

62. O'Quinn RP, Miller JL. The effectiveness of tumor necrosis factor alpha antibody (infliximab) in treating recalcitrant psoriasis: a report of 2 cases. Arch Dermatol. 2002;138(5):644-648. doi:10.1001/archderm.138.5.644

63. Fiehn C, Andrassy K. Case number 29: hitting three with one strike: rapid improvement of psoriatic arthritis, psoriatic erythroderma, and secondary renal amyloidosis by treatment with infliximab (Remicade). Ann Rheum Dis. 2004;63(3):232. doi:10.1136/ ard.2003.014191

64. Yip L, Harrison S, Foley P. From biologic to biologic to biologic: lessons to learn for erythrodermic and recalcitrant chronic plaque psoriasis. Australas $J$ Dermatol. 2008;49(3):152-155. doi:10.1111/j.1440-0960.2008.00463.x

65. Tridico LA, Antonio JR, Mathias CE, Pozetti EMO. Effectiveness and safety of infliximab for 11 years in a patient with erythrodermic psoriasis and psoriatic arthritis. An Bras Dermatol. 2017;92(5):743-745. doi:10.1590/abd1806-4841.20176565

66. Valdés A, Mdel P, Schroeder HF, Roizen GV, Honeyman MJ, Sánchez ML. Efficacy of infliximab in patients with moderate and severe psoriasis treated with infliximab (Remicade). Rev Med Chil. 2006;134(3):326-331. doi:10.4067/s0034-9887200600 0300009

67. Kurokawa R, Hagiwara A, Niijima Y, Kojima K. Computed tomography imaging findings in erythrodermic psoriasis treated with infliximab: a case report. Radiol Case Rep. 2018;13 (2):460-463. doi:10.1016/j.radcr.2018.02.005

68. Belinchon I, Lucas A, Ballester I, Betlloch I, Pérez-Crespo M. Successful treatment of life threatening erythrodermic psoriasis with infliximab. J Am Acad Dermatol. 2009;60(3):AB171.

69. Suárez Pedreira I, Santos Juanes J, Caminal Montero L, Trapiella L. Infliximab: an alternative in refractory erythrodermic psoriasis. Piel. 2006;21(6):317-318. doi:10.1016/S0213-9251(06) 72498-4 
70. Carrasquillo OY, Pabón-Cartagena G, Falto-Aizpurua LA, et al. Treatment of erythrodermic psoriasis with biologics: a systematic review. J Am Acad Dermatol. 2020;83(1):151-158. doi:10.1016/j. jaad.2020.03.073

71. Lee WK, Kim GW, Cho HH, et al. Erythrodermic psoriasis treated with golimumab: a case report. Ann Dermatol. 2015;27 (4):446-449. doi:10.5021/ad.2015.27.4.446

72. Mumoli N, Vitale J, Gambaccini L, Sabatini S, Brondi B, Cei M. Erythrodermic psoriasis. QJM. 2014;107(4):315. doi:10.1093/ qjmed/hct139

73. Richetta AG, Maiani E, Carlomagno V, et al. Treatment of erythrodermic psoriasis in $\mathrm{HCV}+$ patient with adalimumab. Dermatol Ther. 2009;22(Suppl 1):S16-18. doi:10.1111/j.15298019.2009.01266.x

74. Nowsheen S, Kohorst JJ, El-Azhary RA. Adalimumab-induced erythrodermic reactions. Int J Dermatol. 2019;58(10):e204-e206. doi:10.1111/ijd.14503

75. Pescitelli L, Dini V, Gisondi P, et al. Erythrodermic psoriasis treated with ustekinumab: an Italian multicenter retrospective analysis. J Dermatol Sci. 2015;78(2):149-151. doi:10.1016/j. jdermsci.2015.01.005

76. Santos-Juanes J, Coto-Segura P, Mas-Vidal A, Galache Osuna C. Ustekinumab induces rapid clearing of erythrodermic psoriasis after failure of antitumour necrosis factor therapies. $\mathrm{Br}$ $J \quad$ Dermatol. 2010;162(5):1144-1146. doi:10.1111/j.13652133.2010.09669.x

77. Wang TS, Tsai TF. Clinical experience of ustekinumab in the treatment of erythrodermic psoriasis: a case series. J Dermatol. 2011;38(11):1096-1099. doi:10.1111/j.1346-8138.2011.01224.x

78. Kim YS, Kim HJ, Lee S, Park YL. Erythrodermic psoriasis improved by ustekinumab: a report of two cases. Ann Dermatol. 2016;28(1):121-122. doi:10.5021/ad.2016.28.1.121

79. Koutsoukou XA, Papadavid E, Theodoropoulos K, Rigopoulos D. Ustekinumab in severe complicated erythrodermic psoriasis: rapid clearing, safety, and sustained remission. Dermatol Ther. 2014;27(5):257-259. doi:10.1111/dth.12131

80. Stinco G, Piccirillo A, Errichetti E, Bergamo S, Patrone P. Treatment of recalcitrant erythrodermic psoriasis with ustekinumab. Eur $J$ Dermatol. 2014;24(3):387-390. doi:10.1684/ejd.2014.2325

81. Saraceno R, Talamonti M, Galluzzo M, Chiricozzi A, Costanzo A, Chimenti S. Ustekinumab treatment of erythrodermic psoriasis occurring after physical stress: a report of two cases. Case Rep Dermatol. 2013;5(3):254-259. doi:10.1159/000348645

82. Castineiras I, Fernandez-Diaz L, Juarez Y, Lueiro M. Sustained efficacy of ustekinumab in refractory erythrodermic psoriasis after failure of antitumor necrosis factor therapies. $J$ Dermatol. 2012;39(8):730-731. doi:10.1111/j.1346-8138.2011.01499.x

83. Buggiani G, D’Erme AM, Krysenka A, Pescitelli L, Lotti T, Prignano F. Efficacy of ustekinumab in sub-erythrodermic psoriasis: when TNF-blockers fail. Dermatol Ther. 2012;25 (3):283-285. doi:10.1111/j.1529-8019.2012.01465.x

84. Castiñeiras I, Fernández-Diaz L, Juárez Y, Lueiro M. Sustained efficacy of ustekinumab in refractory erythrodermic psoriasis after failure of antitumor necrosis factor therapies. $J$ Dermatol. 2012;39(8):730-731.

85. Concha-Garzón MJ, Godoy-Trapero A, Daudén E, et al. Shortand long-term treatment of erythrodermic psoriasis with ustekinumab: a national and multicenter case series. $J$ Am Acad Dermatol. 2014;70(5):AB189.

86. Errichetti E, Piccirillo A. Latent tuberculosis reactivation in a patient with erythrodermic psoriasis under treatment with ustekinumab and a low dose steroid, despite isoniazid chemoprophylaxis. Eur J Dermatol. 2014;24(4):508-509. doi:10.1684/ejd.2014.2386
87. Sano S, Kubo H, Morishima H, Goto R, Zheng R, Nakagawa H. Guselkumab, a human interleukin-23 monoclonal antibody in Japanese patients with generalized pustular psoriasis and erythrodermic psoriasis: efficacy and safety analyses of a 52-week, phase 3, multicenter, open-label study. $J$ Dermatol. 2018;45 (5):529-539. doi:10.1111/1346-8138.14294

88. Megna M, Ruggiero A, Camela E, Fabbrocini G, Marasca C. A case of erythrodermic psoriasis successfully treated with guselkumab. Dermatol Ther. 2020;33(2):e13238.

89. Chiang CY, Tsai TF. Treatment Response of Patients with Erythrodermic Psoriasis after Switching to Guselkumab. Dermatol Ther (Heidelb). 2021;11(1):301-306. doi:10.1007/ s13555-020-00480-x

90. Suleiman AA, Khatri A, Oberoi RK, Othman AA. ExposureResponse Relationships for the Efficacy and Safety of Risankizumab in Japanese Subjects with Psoriasis. Clin Pharmacokinet. 2020;59 (5):575-589. doi:10.1007/s40262-019-00829-2

91. Weng HJ, Wang TS, Tsai TF. Clinical experience of secukinumab in the treatment of erythrodermic psoriasis: a case series. $\mathrm{Br}$ J Dermatol. 2018;178(6):1439-1440. doi:10.1111/bjd.16252

92. Mugheddu C, Atzori L, Lappi A, Pau M, Murgia S, Rongioletti F. Successful Secukinumab treatment of generalized pustular psoriasis and erythrodermic psoriasis. J Eur Acad Dermatol Venereol. 2017;31(9):e420-e421.

93. Mateu-Puchades A, Santos-Alarcón S, Martorell-Calatayud A, Pujol-Marco C, Sánchez-Carazo JL. Erythrodermic psoriasis and secukinumab: our clinical experience. Dermatol Ther. 2018;31 (4):e12607. doi:10.1111/dth.12607

94. Galluzzo M, D’Adamio S, Campione E, Mazzilli S, Bianchi L, Talamonti M. A clinical case of severe disease burden: an erythrodermic psoriatic patient treated with secukinumab. $J$ Dermatolog Treat. 2018;29(sup1):1-11. doi:10.1080/09546634.2018.1524818

95. Rongioletti F, Mugheddu C, Murgia S. Repigmentation and new growth of hairs after anti-interleukin-17 therapy with secukinumab for psoriasis. JAAD Case Rep. 2018;4(5):486-488. doi:10.1016/j.jdcr.2018.01.006

96. Dogra S, Bishnoi A, Narang T, Handa S. Long-term remission induced by secukinumab in a 13-year-old boy having recalcitrant chronic erythrodermic psoriasis. Dermatol Ther. 2018;31(4): e12611. doi:10.1111/dth.12611

97. Tichy M. Arthropathic psoriasis complicated by a paradoxical reaction in the form of erythrodermic psoriasis following adalimumab and by an allergic reaction following infliximab which was successfully managed with secukinumab. Postepy Dermatol Alergol. 2019;36(4):495-497. doi:10.5114/ada.2019.87454

98. Damiani G, Pacifico A, Russo F, et al. Use of secukinumab in a cohort of erythrodermic psoriatic patients: a pilot study. J Clin Med. 2019;8(6):770. doi:10.3390/jcm8060770

99. Shibata T, Muto J, Takama H, Yanagishita T, Ito T, Watanabe D. Case of psoriatic erythroderma induced by the discontinuation of the chronic use of topical steroid after dialysis initiation and successfully treated with secukinumab. J Dermatol. 2019;46(4): e119-20. doi:10.1111/1346-8138.14649

100. Pizzatti L, Mugheddu C, Sanna S, Atzori L, Rongioletti F. Erythrodermic psoriasis in a dialyzed patient successfully treated with Secukinumab. Dermatol Ther. 2020;33(3):e13348. doi:10.1111/dth.13348

101. Liu LC, Jin XH, Sun C, Xia JX. Two cases of refractory erythrodermic psoriasis effectively treated with secukinumab and a review of the literature. Dermatol Ther. 2021;34:e14825. doi:10.1111/dth. 14825

102. Japanese Ixekizumab Study Group, Saeki H, Nakagawa H, Nakajo K, et al. Efficacy and safety of ixekizumab treatment for Japanese patients with moderate to severe plaque psoriasis, erythrodermic psoriasis and generalized pustular psoriasis: results from a 52-week, open-label, phase 3 study (UNCOVER-J). J Dermatol. 2017;44(4):355-362. doi:10.1111/1346-8138.13622 
103. Okubo Y, Mabuchi T, Iwatsuki K, et al. Long-term efficacy and safety of ixekizumab in Japanese patients with erythrodermic or generalized pustular psoriasis: subgroup analyses of an open-label, phase 3 study (UNCOVER-J). J Eur Acad Dermatol Venereol. 2019;33(2):325-332. doi:10.1111/jdv.15287

104. Megna M, Gallo L, Balato N, Balato A. A case of erythrodermic psoriasis successfully treated with ixekizumab. Dermatol Ther. 2019;32(2):e12825. doi:10.1111/dth.12825

105. Trovato E, Orsini C, Russo F, Cortonesi G, Rubegni P. Ixekizumab as treatment of erythrodermic psoriasis. Dermatol Ther. 2021;34:e14868. doi:10.1111/dth.14868

106. Pangilinan MCG, Sermswan P, Asawanonda P. Use of Anti-IL-17 Monoclonal Antibodies in HIV Patients with Erythrodermic Psoriasis. Case Rep Dermatol. 2020;12(2):132-137. doi:10.1159/000508781

107. Lo Y, Tsai TF. Clinical experience of ixekizumab in the treatment of patients with history of chronic erythrodermic psoriasis who failed secukinumab: a case series. $B r J$ Dermatol. 2019;181 (5):1106-1107. doi:10.1111/bjd.18174

108. Lo Y, Huang YH, Tsai TF. Long-term effectiveness and safety of ixekizumab in the treatment of 14 patients with history of chronic erythrodermic psoriasis who failed prior secukinumab: a bicentric retrospective study. Dermatol Sinica. 2021.

109. Yamasaki K, Nakagawa H, Kubo Y, Ootaki K. Efficacy and safety of brodalumab in patients with generalized pustular psoriasis and psoriatic erythroderma: results from a 52-week, open-label study. Br J Dermatol. 2017;176(3):741-751. doi:10.1111/bjd.14702

110. Bernardini N, Skroza N, Tolino E, et al. Recurrent erythrodermic psoriasis and polycythemia successfully treated with brodalumab. Dermatol Ther. 2020;33(6):e14338. doi:10.1111/dth.14338

111. Megna M, Fabbrocini G, Ferrillo M, Cinelli E. Erythrodermic psoriasis successfully and rapidly treated with brodalumab: report of two cases. Dermatol Ther. 2020;33(6):e14351. doi:10.1111/ dth. 14351

112. Papadavid E, Kokkalis G, Polyderas G, Theodoropoulos K, Rigopoulos D. Rapid clearance of erythrodermic psoriasis with apremilast. J Dermatol Case Rep. 2017;11(2):29-31. doi:10.3315/ jdcr.2017.1246

113. Krishnamoorthy G, Kotecha A, Pimentel J. Complete resolution of erythrodermic psoriasis with first-line apremilast monotherapy. BMJ Case Rep. 2019;12(1):e226959. doi:10.1136/bcr-2018226959

114. Arcilla J, Joe D, Kim J, Kim Y, Truong VN, Jaipaul N. Erythrodermic psoriasis treated with apremilast. Dermatol Rep. 2016;8(1):6599. doi:10.4081/dr.2016.6599

115. Mugheddu C, Pizzatti L, Sanna S, Atzori L, Rongioletti F. COVID-19 pulmonary infection in erythrodermic psoriatic patient with oligodendroglioma: safety and compatibility of apremilast with critical intensive care management. J Eur Acad Dermatol Venereol. 2020;34(8):e376-e378. doi:10.1111/jdv.16625

116. Megna M, Fabbrocini G, Camela E, Cinelli E. Apremilast efficacy and safety in elderly psoriasis patients over a 48-week period. J Eur Acad Dermatol Venereol. 2020;34(11):e705-e707. doi:10.1111/jdv.16443

117. Beltran Monasterio EP. Low-dose Naltrexone: an Alternative Treatment for Erythrodermic Psoriasis. Cureus. 2019;11(1): e3943. doi:10.7759/cureus.3943
118. Nishizawa A, Satoh T, Yokozeki H. Erythrodermic psoriasis improved by panitumumab, but not bevacizumab. Acta Derm Venereol. 2012;92(4):360-361. doi:10.2340/00015555-1348

119. Kharaeva Z, Gostova E, De Luca C, Raskovic D, Korkina L. Clinical and biochemical effects of coenzyme Q10, vitamin E, and selenium supplementation to psoriasis patients. Nutrition. 2009;25(3):295-302. doi:10.1016/j.nut.2008.08.015

120. Gregoire ARF, DeRuyter BK, Stratman EJ. Psoriasis Flares Following Systemic Glucocorticoid Exposure in Patients With a History of Psoriasis. JAMA Dermatol. 2021;157(2):198-201. doi:10.1001/jamadermatol.2020.4219

121. Mrowietz U, Domm S. Systemic steroids in the treatment of psoriasis: what is fact, what is fiction? J Eur Acad Dermatol Venereol. 2013;27(8):1022-1025. doi:10.1111/j.14683083.2012.04656.x

122. Cretu S, Salavastru CM, Tiplica GS. Treatment of psoriatic erythroderma using systemic corticosteroids: a timeless option? Dermatol Ther. 2020;33(6):e14222. doi:10.1111/dth.14222

123. Pang ML, Murase JE, Koo J. An updated review of acitretin-a systemic retinoid for the treatment of psoriasis. Expert Opin Drug Metab Toxicol. 2008;4(7):953-964. doi:10.1517/ 17425255.4.7.953

124. van der Vleuten CJ, Gerritsen MJ, Steijlen PM, de Jong EM. A therapeutic approach to erythrodermic psoriasis: report of a case and a discussion of therapeutic options. Acta Derm Venereol. 1996;76(1):65-67. doi:10.2340/00015555766567

125. Reynolds KA, Pithadia DJ, Lee EB, Liao W, Wu JJ. A systematic review of treatment strategies for erythrodermic psoriasis. J Dermatolog Treat. 2021;32(1):49-55. doi:10.1080/ 09546634.2019.1689228

126. Shao S, Wang G, Maverakis E, Gudjonsson JE. Targeted Treatment for Erythrodermic Psoriasis: rationale and Recent Advances. Drugs. 2020;80(6):525-534. doi:10.1007/s40265020-01283-2

127. Hsu SH, Tsai TF. Evolution of the inclusion/exclusion criteria and primary endpoints in pivotal trials of biologics and small oral molecules for the treatment of psoriasis. Expert Rev Clin Pharmacol. 2020;13(3):211-232. doi:10.1080/ 17512433.2020 .1743175

128. Li X, Andersen KM, Chang HY, Curtis JR, Alexander GC. Comparative risk of serious infections among real-world users of biologics for psoriasis or psoriatic arthritis. Ann Rheum Dis. 2020;79(2):285-291. doi:10.1136/annrheumdis-2019-216102

129. Ger TY, Huang YH, Hui RC, Tsai TF, Chiu HY. Effectiveness and safety of secukinumab for psoriasis in real-world practice: analysis of subgroups stratified by prior biologic failure or reimbursement. Ther Adv Chronic Dis. 2019;10:2040622319843756. doi:10.1177/2040622319843756

130. Tsai YC, Tsai TF. Switching biologics in psoriasis - practical guidance and evidence to support. Expert Rev Clin Pharmacol. 2020;13(5):493-503. doi:10.1080/17512433.2020.1767590

131. Huang YW, Tsai TF. Efficacy of tofacitinib in patients with moderate-to-severe psoriasis who had inadequate responses to prior biologics. Dermatol Sinica. 2019;37(4):205-208.

Psoriasis: Targets and Therapy

Dovepress

Publish your work in this journal

Psoriasis: Targets and Therapy is international, peer-reviewed, open access journal focusing on psoriasis, nail psoriasis, psoriatic arthritis and related conditions, identification of therapeutic targets and the

optimal use of integrated treatment interventions to achieve improved outcomes and quality of life. Visit http://www.dovepress. $\mathrm{com} /$ testimonials.php to read real quotes from published authors. 